\title{
UTILIZATION OF BINAHONG (Anredera cordifolia) LEAVES EXTRACT FROM BOGOR REGENCY AS FREE RADICAL SCAVENGING ACTIVITY
}

Novi Fajar Utami, Usep Suhendar* dan Anisa Hidayatul Amini

Program Studi Farmasi, Fakultas MIPA, Universitas Pakuan, Bogor, Indonesia

\section{ARTICLE INFO}

Article history:

Received 26 Jul 2021,

Revised 18 Jan 2021,

Accepted 28 Jan 2022,

Available online 29 Jan 2022

Keywords:

$\checkmark$ Binahong

$\checkmark \quad$ Response surface methodology

$\checkmark \quad$ Yield

$\checkmark \quad$ free radical scavenging activity

*corresponding author: usep.suhendar@unpak.ac.id Phone: +6281311784664

https://doi.org/10.31938/jsn.v $\underline{12 \mathrm{i} 1.327}$

\begin{abstract}
Binahong leaves contain flavonoid and polyphenol compounds that are potentially free radical scavengers. Extraction using ultrasonic has been carried out at various extraction times and temperatures. The purpose of this study was to obtain the optimum time and temperature of ultrasonic for yield and free radical scavenging activity of binahong leaves using Response Surface Methodology (RSM) with the Central Composite Design method. Binahong leaves were extracted at three levels of time (10,20, 30 minutes) and temperature $\left(40,45,50^{\circ} \mathrm{C}\right)$ with a frequency of $40 \mathrm{kHz}$ using an ultrasonic bath. The results showed at a temperature of $45^{\circ} \mathrm{C}$ for 20 minutes obtained the highest yield of $10.44 \%$, with a predictive value of RSM $10.15 \%$. At a temperature of $40^{\circ} \mathrm{C}$ for 30 minutes, the optimum value of the free radical scavenging activity of binahong leaf extract was obtained. The percent inhibition value was $55.92 \%$, with a predictive value of $48.85 \%$. Based on the results, the temperature and time variables have a significant effect on the percentage of extract yield and have no significant effect on free radical scavenging activity.
\end{abstract}

\section{ABSTRAK}

\section{Pemanfaatan Ekstrak Daun Binahong (Anredera cordifolia ) Asal Kabupaten Bogor Sebagai Penangkal Radikal Bebas}

Daun binahong memiliki senyawa flavonoid dan polifenol yang berpotensi sebaga penangkal radikal bebas. Telah dilakukan ekstraksi dengan menggunakan bantuan gelombang ultrasonic yang dilakukan dengan berbagai waktu dan suhu ekstraksi. Tujuan dari penelitian ini yaitu diperolehnya waktu dan suhu optimum ekstraksi berbantu gelombang ultrasonik terhadap rendemen ekstrak dan aktivitas penangkal radikal bebas daun binahong dengan menggunakan Response Surface Methodology (RSM) metode Central Composite Design. Daun binahong diekstraksi dengan 3 taraf waktu (10, 20, 30 menit) dan suhu $\left(40^{\circ} \mathrm{C}, 45^{\circ} \mathrm{C}, 50^{\circ} \mathrm{C}\right)$ dengan frekuensi $40 \mathrm{kHz}$ dengan menggunakan ultrasonic bath. Hasil penelitian menunjukkan bahwa pada suhu $45^{\circ} \mathrm{C}$ pada waktu 20 menit diperoleh hasil rendemen ekstrak tertinggi yaitu 10,44\% dengan nilai prediksi RSM 10,15\% dan pada suhu $40^{\circ} \mathrm{C}$ dengan waktu 30 menit diperoleh nilai optimum terhadap aktivitas penangkal radikal bebas ekstrak daun binahong yaitu diperoleh nilai persen inhibisi 55,92\% dengan nilai prediksi $48,85 \%$. Berdasarkan hasil penelitian, menunjukkan bahwa variabel suhu dan waktu hanya berpengaruh nyata terhadap persentase rendemen ekstrak dan tidak berpengaruh nyata terhadap aktivitas penangkalan radikal bebas.

Kata kunci: Binahong, Response surface methodology, Rendemen ekstrak, Aktivitas penangkal radikal bebas

\section{PENDAHULUAN}

Binahong merupakan tanaman yang memiliki genus Anredera dan merupakan Famili Basellaceae, pada beberapa penelitian menyatakan bahwa pada hasil isolasi daun binahong (Anredera cordifolia (Ten.) Steenis) mengandung saponin triterpen (Arif et al., 2008), flavonoid, steroid (Ayu et al., 2018) dan polifenol
(Kurniawan \& Aryana, 2015). Flavonoid merupakan senyawa fenolik yang terdapat di alam yang berpotensi sebagai penangkal radikal bebas (Parwati et al., 2014).

Penarikan suatu senyawa dalam daun binahong membutuhkan suatu metode ekstraksi. Dalam pengujian fitokimia, proses ekstraksi sangat penting karena dari tahap awal hingga akhir menggunakan proses ekstraksi. Ekstraksi 
yaitu suatu metode pemisahan dari campurannya dengan menggunakan pelarut tertentu. Suhu dan waktu merupakan parameter yang dapat mempengaruhi ekstraksi, sehingga peningkatan suhu dan waktu harus diperhatikan karena suhu yang terlalu tinggi dapat merusak bahan yang akan diproses dan waktu ekstraksi yang tepat dapat menghasilkan senyawa yang optimal (Ibrahim et al., 2015). Pada penelitian ini menggunakan ekstraksi berbantu gelombang ultrasonik. Ekstraksi berbantu gelombang ultrasonik yaitu ekstraksi yang dilakukan dengan bantuan gelombang ultrasonik pada frekuensi 20$2000 \mathrm{kHz}$ (Sekarsari et al., 2019).

Response Surface Methodology yaitu suatu metode statistik dan matematik yang digunakan untuk membangun, mengembangkan serta mengoptimasi proses. Untuk mengetahui suhu dan waktu ekstraksi yang tepat maka dilakukan optimasi untuk menentukan nilai optimum dari variasi suhu dan waktu ekstraksi. Proses optimasi dilakukan dengan menggunakan RSM, karena pada penelitian Kunarto et al, (2019) menyatakan bahwa dengan menggunakan metode RSM dapat menghasilkan waktu, suhu dan konsentrasi pelarut yang optimal dari ektraksi biji melinjo kerikil berbantu gelombang ultrasonik.

Penelitian terkait optimasi suhu dan waktu pada ekstraksi berbantu gelombang ultrasonik terhadap rendemen ekstrak dan aktivitas penangkalan radikal bebas daun binahong (Anredera cordofolia) menggunakan metode optimasi Response Surface Methodology (RSM) belum pernah dilaporkan. Berdasar uraian di atas maka sangat perlu dilakukan penelitian terkait optimasi suhu dan waktu ekstraksi berbantu gelombang ultrasonik terhadap rendemen esktrak dan aktivitas penangkal radikal bebas daun binahong menggunakan metode optimasi RSM dengan rancangan Central Composite Design. Tujuan penelitian yaitu menentukan suhu dan waktu optimum ekstraksi berbantu gelombang ultrasonik terhadap persentase rendemen ekstrak dan untuk mengetahui aktivitas penghambatan radikal bebas yang optimum pada ekstrak daun binahong.

\section{BAHAN DAN METODE KERJA}

\section{Bahan dan Alat}

Penelitian dilakukan pada Tahun 2021, di Laboratorium Farmasi Fakultas Matematika dan Ilmu Pengetahuan Alam Universitas Pakuan Bogor.
Bahan penelitian meliputi daun binahong (Anredera cordifolia (Ten.) Steen), metanol 96\%, $\mathrm{DPPH}$, vitamin $\mathrm{C}$, air suling, heksana, pereaksi Dragendroff, pereaksi Bouchardat, pereaksi Mayer, larutan $10 \%$ besi (III), metanol 50\%, asam klorida $(\mathrm{HCl})$, serbuk $\mathrm{Mg}$, serbuk $\mathrm{Zn}$, pereaksi Liebermann-Burchard, gelatin, larutan $3 \%$ besi (III), natrium klorida $(\mathrm{NaCl})$. Alat penelitian meliputi timbangan analitik, blender, ayakan 40 mesh, sonikator, rotary evaporator, pipet tetes, alat-alat gelas, waterbath, spektrofotometer UVVis, alat sentrifugasi, Alat Pelindung Diri (APD), kertas saring Whattman, aluminium foil.

\section{Metode}

\section{Pengumpulan bahan dan determinasi}

Dalam penelitian ini sampel yang digunakan yaitu seluruh bagian daun binahong (Anredera cordifolia (Ten.) Steen) yang diperoleh dari Kabupaten Bogor. Selanjutnya determinasi dilakukan di Lembaga Ilmu Pengetahuan Indonesia Kebun Raya Bogor.

\section{Pembuatan serbuk daun binahong}

Seluruh bagian daun binahong (Anredera cordifolia (Ten.) Steen) segar sebanyak $17,889 \mathrm{~kg}$ dicuci dan disortasi basah. Selanjutnya daun dikeringkan di bawah sinar matahari langsung. Kemudian daun binahong yang sudah kering dihaluskan dengan menggunakan blender dan diayak dengan ayakan 40 mesh.

\section{Optimasi ekstraksi dengan Response Surface Methodology (RSM)}

Proses ekstraksi berdasarkan hasil analisis perangkat lunak Design Expert 11.1.2.0 Trial dengan menggunakan rancangan percobaan Central Composite Design. Faktor atau variabel yang digunakan yaitu suhu ekstraksi yaitu $40^{\circ} \mathrm{C}$, $45^{\circ} \mathrm{C}, 50^{\circ} \mathrm{C}$ dan waktu ekstraksi $10,20,30$ menit (Sekarsari et al., 2019). Setelah data dimasukkan ke dalam perangkat lunak Design Expert 11.1.2.0 Trial, akan diperoleh 13 kombinasi perlakuan untuk ekstraksi dengan bantuan gelombang ultrasonik.

Pembuatan ekstrak daun binahong berdasarkan hasil kombinasi analisis perangkat lunak yaitu dengan cara serbuk daun binahong ditimbang 100 gram dengan menggunakan pelarut metanol 95\% $1000 \mathrm{~mL}$ (1:10). Kemudian sampel diekstraksi berdasarkan hasil 13 kombinasi analisis RSM dengan menggunakan alat sonikator dengan frekuensi gelombang 40 kHz. Selanjutkan ekstrak cair disaring dan dipekatkan dengan rotary vaccum evaporator. 
Kemudian ekstrak cair dikentalkan dengan menggunakan water bath pada suhu $70^{\circ} \mathrm{C}$ hingga menjadi ekstrak pekat. Selanjutnya dihitung persentase rendemen ekstrak.

$$
\% \text { Rendemen }=\frac{\text { Bobot akhir }}{\text { Bobot awal }} \times 100 \%
$$

Tabel 1. Hasil kombinasi perlakuan Response Surface Methodology

\begin{tabular}{cccc}
\hline Std & Run & $\begin{array}{c}\text { Suhu } \\
\left({ }^{\circ} \mathbf{C}\right)\end{array}$ & $\begin{array}{c}\text { Waktu } \\
(\text { Menit })\end{array}$ \\
\hline 12 & 1 & 45 & 20 \\
10 & 2 & 45 & 20 \\
1 & 3 & 40 & 10 \\
5 & 4 & 38 & 20 \\
7 & 5 & 45 & 6 \\
2 & 6 & 50 & 10 \\
9 & 7 & 45 & 20 \\
3 & 8 & 40 & 30 \\
6 & 9 & 52 & 20 \\
4 & 10 & 50 & 30 \\
8 & 11 & 45 & 34 \\
11 & 12 & 45 & 20 \\
13 & 13 & 45 & 20 \\
\hline
\end{tabular}

\section{Uji karakteristik simplisia dan ekstrak} Uji kadar air

Uji kadar air ditentukan menggunakan metode gravimetri, yaitu dengan cara sampel sebanyak 2 gram dimasukkan ke dalam cawan penguap. Sampel dimasukkan ke dalam oven pada suhu $105^{\circ} \mathrm{C}$ selama 5 jam, selanjutnya ditimbang sampai bobot konstan. Penetapan kadar air dilakukan secara duplo.

\section{Uji kadar abu}

Sampel sebanyak 2 gram dimasukkan ke dalam kurs porselin. Sampel dimasukkan ke dalam tanur dengan suhu $\pm 600^{\circ} \mathrm{C}$ dengan waktu 6 jam sampai arang habis. Pengujian dilakukan secara duplo.

Uji aktivitas penangkalan radikal bebas dengan metode DPPH (Utami et al, 2018)

\section{a. Larutan DPPH 1 mM}

DPPH sebanyak 98,58 mg ditimbang, dimasukkan ke dalam labu ukur $250 \mathrm{~mL}$. DPPH dilarutkan dengan menggunakan pelarut metanol p.a hingga batas labu. Kemudian labu ukur dilapisi aluminium foil.

\section{b. Larutan blanko}

$1 \mathrm{~mL}$ larutan DPPH $1 \mathrm{mM}$ dimasukkan ke dalam labu ukur dan ditambah $10 \mathrm{~mL}$ metanol p.a dan dihomogenkan. Labu ukur dilapisi dengan menggunakan aluminium foil dan diinkubasi pada suhu kamar yaitu $25-30^{\circ} \mathrm{C}$.

\section{c. Larutan baku vitamin C $100 \mathrm{mg} / \mathrm{L}$}

Vitamin C dimasukkan ke dalam labu ukur $100 \mathrm{~mL}$ sebanyak $100 \mathrm{mg}$, ditambahkan metanol p.a sampai batas labu (1000 mg/L). $10 \mathrm{~mL}$ larutan vitamin C $1000 \mathrm{mg} / \mathrm{L}$ dimasukan ke dalam labu ukur $100 \mathrm{~mL}$ dilarutkan dengan metanol p.a.

\section{Penentuan panjang gelombang maksimum}

Metanol p.a sebanyak $8 \mathrm{~mL}$ dipipet dan ditambahkan $1 \mathrm{~mL}$ larutan DPPH $1 \mathrm{mM}$ dan diencerkan dengan metanol p.a sampai batas pada labu ukur $10 \mathrm{~mL}$. Labu ukur dilapisi dengan aluminium foil dan selanjutnya diinkubasi pada suhu kamar selama 30 menit.

\section{Penentuan waktu inkubasi optimum}

$1 \mathrm{~mL}$ larutan standar vitamin $\mathrm{C}$ dimasukkan ke dalam labu ukur $10 \mathrm{~mL}$. Metanol p.a $4 \mathrm{~mL}$ dan larutan DPPH $1 \mathrm{mM}$ sebanyak $1 \mathrm{~mL}$ dipipet dan ditambahkan metanol p.a sampai tanda batas labu. Absorban diukur pada panjang gelombang maksimum dan diukur pada waktu 10, 20, 30, 40, 50, 60 menit.

\section{Pembuatan deret larutan standar vitamin C}

Pembuatan deret vitamin $\mathrm{C}$ dengan variasi konsentrasi yaitu 2, 4, 6, 8, $10 \mathrm{mg} / \mathrm{L}$ dibuat dalam labu ukur $10 \mathrm{~mL}$. Larutan DPPH $1 \mathrm{mM}$ sebanyak $1 \mathrm{~mL}$ dimasukkan dalam labu dan ditambahkan metanol p.a hingga tanda batas labu. Selanjutnya larutan diinkubasi dengan waktu optimum dan diukur pada panjang gelombang maksimum dengan menggunakan alat spektrofotometer UVVis.

\section{Pembuatan larutan uji dari 13 kombinasi hasil analisis RSM}

Larutan uji dibuat dengan cara membuat larutan induk 1000 mg/L. Larutan dimasukkan ke dalam labu ukur $50 \mathrm{~mL}$ dan dilarutkan dengan metanol p.a sampai tanda batas. Konsentrasi 50 $\mathrm{mg} / \mathrm{L}$ dibuat dari larutan induk $1000 \mathrm{mg} / \mathrm{L} \mathrm{ke}$ dalam labu ukur $10 \mathrm{~mL}$. Metanol p.a $4 \mathrm{~mL}$ dan larutan DPPH $1 \mathrm{mM}$ sebanyak $1 \mathrm{~mL}$ ditambahkan ke dalam labu lalu metanol p.a ditambahkan hingga tanda batas, kemudian labu dilapisi aluminium foil.

\section{Pengujian penangkalan radikal bebas}

Larutan uji dari 13 perlakuan, deret larutan kontrol positif vitamin $\mathrm{C}$ dan blanko diukur absorbannya dengan menggunakan alat spektrofotometer UV-Vis. Nilai persentase 
hambatan DPPH dihitung dengan menggunakan nilai $I C$ dengan perhitungan sebagai berikut.

$\%$ Inhibisi $=\frac{\text { Abs blanko DPPH }- \text { Abssampel }}{\text { absorbansi blanko DPPH }} \times 100 \%$

\section{Pengolahan data}

Hasil data persentase rendemen dan persentase inhibisi diperoleh dari hasil ekstraksi 13 kombinasi perlakuan, kemudian diolah dengan analisis RSM menggunakan perangkat lunak Design Expert 11.1.2.0 Trial dengan rancangan Central Composite Design (CCD) untuk menetapkan kondisi hasil optimum ekstraksi analisis RSM terhadap pengaruh pada faktor suhu dan waktu ekstraksi terhadap persentase rendemen dan uji aktivitas penangkalan radikal bebas. kemudian data diuji dengan ANOVA menggunakan tingkat kepercayaan $95 \%$.

\section{Uji fitokimia}

\section{Pengujian alkaloid}

Ekstrak ditimbang sebanyak 0,5 gram, lalu ditambahkan $1 \mathrm{~mL} \mathrm{HCl} 2 \mathrm{~N}$ dan $9 \mathrm{~mL}$ air. Selajutnya larutan dipanaskan di atas penangas air selama 15 menit, larutan didinginkan dan disaring. Hasil filtrat digunakan untuk pengujian. Filtrat diteteskan pada kaca arloji, ditambahkan reagen Dragendroff, Mayer dan Bouchardat.

\section{Pengujian flavonoid}

Identifiksai senyawa flavonid dilakukan dengan menggunakan beberapa pereaksi flavonoid, yaitu a. Ekstrak ditimbang sebanyak 0,5 gram, dilarutkan dalam 1 - $2 \mathrm{~mL}$ metanol 50\%, jika perlu dengan menggunakan pemanasan di atas penangas air, kemudian larutan ditambahkan logam magnesium dan ditambahkan 5-6 tetes asam klorida pekat. Selanjutnya larutan dipanaskan beberapa menit di atas penangas air, warna merah hingga merah lembayung yang timbul menandakan adanya senyawa flavonon, flavonol, flavanonol, dan dihidroflavonol.

b. Ekstrak ditimbang sebanyak 0,5 gram, dilarutkan dalam 1 - $2 \mathrm{ml}$ metanol 50\%, di panaskan diatas penangas air, kemudian larutan ditambahkan sedikit serbuk seng dan ditambahkan 5-6 tetes asam klorida pekat. Selanjutnya larutan dipanaskan beberapa menit di atas penangas air. Timbulnya warna merah lembayung menunjukan adanya senyawa dihidroflavonol, flavanon dan positif mengandung flavonoid jika larutan tidak berwarna atau berwarna merah muda lemah.

\section{Pengujian steroid dan triterpenoid}

Ekstrak sebanyak 1 gram dimasukkan ke dalam tabung reaksi, lalu ditambahkan $2 \mathrm{~mL}$ heksana. Larutan dikocok perlahan dan ditambahkan pereaksi Liebermann-Burchard. Timbulnya warna merah atau ungu menunjukan positif mengandung triterpenoid, dan larutan positif steroid jika larutan berubah menjadi warna biru atau hijau.

\section{Pengujian saponin}

Ekstrak daun binahong sebanyak 1 gram, ditambahkan $10 \mathrm{~mL}$ air panas lalu didinginkan. Larutan dikocok kuat-kuat sampai menghasilkan busa, lalu ditambahkan asam klorida yang bertujuan agar busa tetap stabil.

\section{Pengujian tanin}

Ekstrak daun binahong ditimbang sebanyak 0,5 gram, ditambahkan aquadest panas lalu diaduk dan didinginkan. Selanjutnya ditambahkan larutan gelatin 10\%, adanya tanin ditandai timbulnya endapan warna putih. Ekstrak ditambahkan $\mathrm{NaCl}$-gelatin dengan perbandingan 1:1. Hasil positif tannin ditandai dengan timbulnya endapan pada larutan. Ekstrak ditambahkan dengan larutan 3\% besi (III) klorida, adanya tanin ditandai timbulnya warna hijau biru hingga kehitaman.

\section{HASIL DAN PEMBAHASAN}

\section{Hasil pembuatan serbuk}

Daun binahong basah sebanyak $17,889 \mathrm{~kg}$ setelah dikeringkan dan diblender diperoleh 1,336 $\mathrm{kg}$ dengan persentase rendemen serbuk yaitu 7,4682 . Serbuk daun binahong yang dihasilkan berwarna hijau, bau aromatik, serbuk kasar dan tidak ada rasa.

\section{Hasil uji karakteristik simplisia dan ekstrak}

Penetapan kadar air yaitu tahapan standarisasi parameter nonspesifik dengan menggunakan metode gravimetri. Penetapan kadar air ini bertujuan untuk mengetahui rentang atau batas minimal kandungan air yang diperbolehkan dalam suatu bahan. Jika suatu bahan mengandung jumlah air yang tinggi maka akan semakin mudah ditumbuhi mikroorganisme 
serta dapat merusak senyawa dalam simplisia dan dapat pula mengurangi umur simpan bahan (DepKes RI., 2000). Hasil penetapan kadar air serbuk daun binahong diperoleh rata-rata 6,4922 $\%$ dan kadar air ekstrak daun binahong diperoleh rata-rata 4,5949\%. Hasil penetapan kadar air sudah memenuhi syarat sesuai dengan literatur yaitu kurang dari 10\% (BPOM et al., 2019).

Penetapan kadar abu bertujuan untuk mengidentifikasi zat anorganik dan mineral setelah proses pengabuan (Arif et al., 2008). Penetapan kadar abu yaitu dilakukan dengan cara sampel ditanur dimasukkan kedalam oven dengan suhu tinggi sampai menjadi abu dan menyisakan unsur-unsur mineral dan anorganik. Hasil penetapan kadar abu serbuk simplisia yaitu dengan rata-rata 6,26895\% dan kadar abu ekstrak daun binahong diperoleh rata-rata yaitu 6,0761\%. Hasil penetapan kadar abu simplisia dan ekstrak daun binahong sudah memenuhi syarat yaitu kurang dari 16,6 \% (DepKes RI, 2008).

\section{Hasil uji fitokimia serbuk dan ekstrak}

Uji fitokimia dilakukan dengan menggunakan analisis kualitatif yaitu mengamati perubahan warna pada setiap penambahan pereaksi. Uji fitokimia ini bertujuan untuk mengetahui kandungan yang terdapat pada ekstrak. Pengujian ekstrak daun binahong diantaranya yaitu alkaloid, flavonoid, steroid, triterpen, saponin dan tanin.

Dari hasil pengamatan yang telah diperoleh pada uji fitokimia ekstrak daun binahong diperoleh bahwa reaksi positif terdapat pada senyawa alkaloid, flavonoid, steroid, triterpen, saponin dan tanin. Hasil penelitian ini sesuai dengan yang dilakukan oleh Ayu et al., (2018) menyatakan bahwa ekstrak daun binahong mengandung senyawa alkaloid, flavonoid, steroid, triterpen dan saponin. Parwati et al., (2014) juga menyatakan bahwa daun binahong mengandung senyawa tanin. Sehingga pada penelitian ini tidak menyebabkan adanya perbedaan hasil pada penelitian sebelumnya.

Setelah diperoleh hasil persentase rendemen tertinggi selanjutnya dilakukan analisis dengan menggunakan RSM dengan menggunakan rancangan Central Composite Design (CCD) untuk melihat kondisi optimal dari faktor-faktor ekstraksi yang digunakan.

Tabel 2 Hasil Optimasi Ekstraksi Daun Binahong

\begin{tabular}{ccccc}
\hline No. & Suhu $\left({ }^{\circ} \mathrm{C}\right)$ & Waktu (Menit) & $\begin{array}{c}\text { Rendemen } \\
(\%)\end{array}$ & $\begin{array}{c}\text { Inhibisi } \\
(\%)\end{array}$ \\
\hline 1 & & & $\mathbf{1 0 , 4 4}$ & 46,17 \\
2 & 45 & 20 & 10,43 & 49,54 \\
3 & 45 & 20 & 6,47 & 49,07 \\
4 & $40 /$ & 10 & 7,36 & 30,87 \\
5 & 38 & 20 & 7,15 & 33,87 \\
6 & 45 & 6 & 8,18 & 41,87 \\
7 & 50 & 10 & 9,62 & 33,99 \\
8 & 45 & 20 & 6,62 & $\mathbf{5 5 , 9 2}$ \\
9 & 40 & 30 & 7,89 & 22,78 \\
10 & 52 & 20 & 7,68 & 25,64 \\
11 & 50 & 30 & 8,50 & 38,29 \\
12 & 45 & 34 & 10,44 & 45,59 \\
13 & 45 & 20 & 9,77 & 48,04 \\
\hline
\end{tabular}




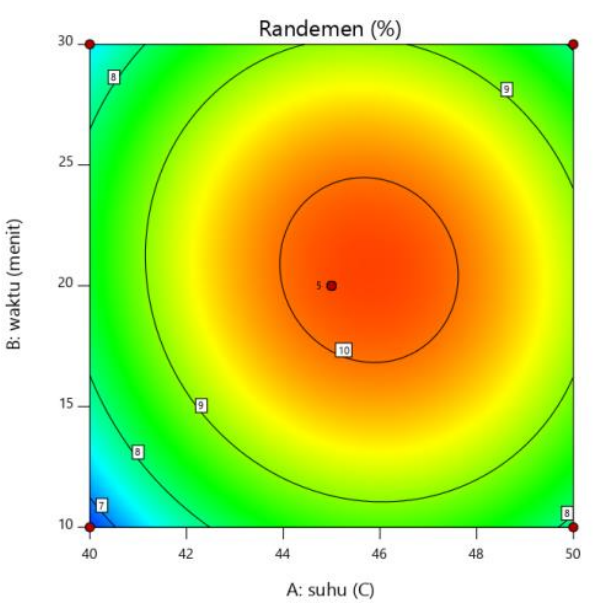

(a)

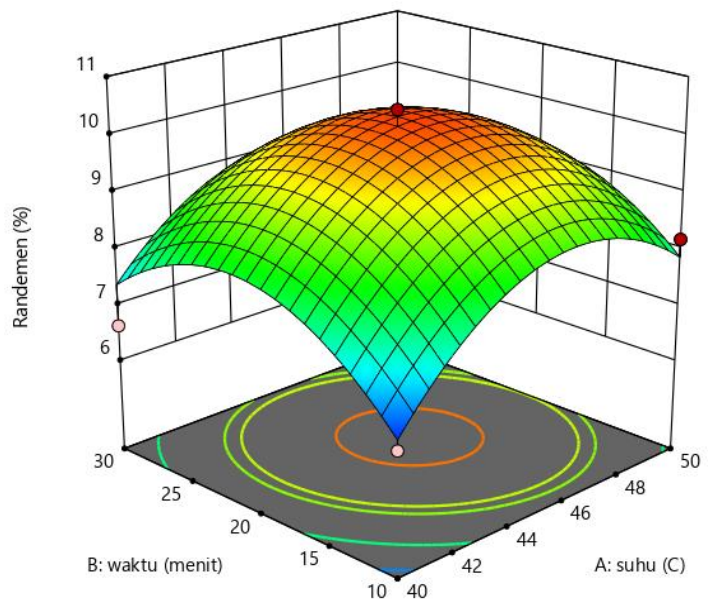

(b)

Gambar 1. Contour plot 2D terhadap rendemen ekstrak (a)

Surface plot 3D terhadap rendemen ekstrak (b)

Pada Gambar 1 menunjukan adanya interaksi antara faktor-faktor dari variabel ekstraksi yaitu suhu dan waktu terhadap persentase rendemen ekstrak. Semakin lama waktu ekstraksi mencapai titik waktu optimum maka semakin tinggi persentase rendemen ekstrak yang dihasilkan, karena kontak antara bahan yang digunakan dengan pelarut akan semakin tinggi. Sehingga kelarutan bahan yang digunakan akan terus meningkat hingga pelarut mencapai pada titik kesetimbangan. Namun, semakin lama waktu yang digunakan untuk ekstraksi serta melebihi waktu optimum maka rendemen ekstrak yang diperoleh akan menurun. Waktu ekstraksi yang terlalu lama dan melebihi waktu optimum akan merusak senyawa yang diekstrak (Andriani et al., 2019). Hasil penelitian menunjukan bahwa waktu optimum ekstraksi yaitu pada menit ke 20 .

Suhu ekstraksi juga mempengaruhi hasil rendemen ekstrak, apabila suhu yang digunakan saat ekstraksi semakin tinggi maka persentase rendemen yang dihasilkan akan meningkat. Namun, suhu ekstraksi yang terlalu tinggi akan menyebabkan menurunnya persentase rendemen ekstrak. Karena suhu yang terlalu tinggi dapat merusak senyawa bioaktif yang terdapat dalam bahan yang digunakan yaitu senyawa yang tidak tahan akan panas, sehingga rendemen yang dihasilkan akan menurun (Cahayanti et al, 2016). Dari hasil penelitian diperoleh suhu ekstraksi optimum pada suhu $45^{\circ} \mathrm{C}$. Berdasarkan Gambar 1 countour plot 2D dan surface plot $3 \mathrm{D}$, rendemen tertinggi berada di daerah berwarna merah dan bagian terendah berada didaerah berwarna biru.

Berdasarkan hasil uji Analysis of Variance (ANOVA) terhadap respon persentase rendemen ekstrak diperoleh nilai $\mathrm{P}$ 0,0012 yang artinya model yang digunakan berpengaruh nyata atau signifikan terhadap respon. Respon berpengaruh nyata apabila nilai P kurang dari 5\% (Ernes et al., 2014). Sedangkan nilai ketidaktepatan pengujian atau lack of fit diperoleh nilai P-value 0,1551 $(>0,05)$ tidak signifikan sehingga dapat disimpulkan bahwa model yang digunakan sudah sesuai. Berdasarkan model polinomial kuadratik diperoleh nilai $\mathrm{R}^{2}$ (koefisien determinasi) yaitu 0,9161 atau $91,26 \%$, hal ini menunjukan bahwa model sangat sesuai dan dapat digunakan untuk memprediksi persentase rendemen ekstrak dengan mengunakan UAE. Sedangkan nilai Adjusted $\mathrm{R}^{2}$ yaitu 0,8562 atau $85,62 \%$ dimana nilai $\mathrm{R}^{2}>70 \%$ yang menunjukan bahwa nilai actual dan prediksi cukup tepat dalam memberikan kedekatan hasil yang diperoleh (Sari et al., 2015).

Diperoleh persamaan kanonikal yang diperoleh dari analisis model dan ragam :

$$
\begin{aligned}
& \mathrm{Y}=10,15+0,4437 \mathrm{~A}+0,1946 \mathrm{~B}-0,1632 \mathrm{~A} * \mathrm{~B} \\
& \quad-1,40 \mathrm{~A}^{2}-1,30 \mathrm{~B}^{2} \\
& \text { Keterangan } \quad \text { (1) } \\
& \mathrm{Y} \quad=\text { Rendemen ekstrak }(\%) \\
& \mathrm{A} \quad=\text { Suhu }\left({ }^{\circ} \mathrm{C}\right) \\
& \mathrm{B} \quad=\text { Waktu (Menit) } \\
& \mathrm{A}^{* \mathrm{~B}} \quad \text { = Interaksi suhu dan waktu } \\
& \mathrm{A}^{2} \quad=\text { Waktu ditingkatkan dua kali } \\
& \mathrm{B}^{2} \quad=\text { Waktu ditingkatkan dua kali }
\end{aligned}
$$

Pada persamaan 1 menunjukan bahwa persentase rendemen berbanding lurus dengan faktor suhu dan waktu, artinya kenaikan persentase rendemen dipengaruhi oleh kenaikan faktor suhu dan waktu yang ditandai dengan tanda positif pada persamaan, sedangkan pada faktor interaksi suhu dengan waktu dan faktor suhu dan waktu yang dinaikan dua kalinya akan 
menyebabkan penurunan pada persentase rendemen yang ditandai dengan tanda minus pada persamaan.

\section{Hasil optimasi uji aktivitas penangkalan radikal bebas ekstrak}

Penelitian ini dilakukan pengujian aktivitas penangkalan radikal bebas daun binahong menggunakan metode DPPH merujuk pada penelitian Jami' ah et al (2018).

Pengujian aktivitas penangkalan radikal bebas dilakukan secara kuantitatif yaitu dengan mengukur absorbansi DPPH dengan menggunakan panjang gelombang dari DPPH yaitu $515,5 \mathrm{~nm}$. Pada uji aktivitas penangkal radikal bebas perubahan warna dari ungu menjadi kuning. Setelah diperoleh panjang gelombang maksimum DPPH, selanjutnya yaitu menentukan waktu inkubasi yang optimum. Waktu inkubasi optimum merupakan waktu yang dapat mengoptimumkan antara reaksi DPPH dengan sampel yang akan diujikan. Dari hasil pengukuran diperoleh waktu inkubasi optimum yaitu 40 menit.

Berdasarkan Tabel 2 hasil dari optimasi daun binahong terhadap aktivitas penangkal radikal bebas dengan konsentrasi sampel $50 \mathrm{mg} / \mathrm{L}$, diperoleh \% inhibisi tertinggi yaitu pada suhu $40^{\circ} \mathrm{C}$ waktu 30 menit dengan nilai \% inhibisi sebesar 55,92\%. Faktor-faktor yang mempengaruhi aktivitas suatu penangkal radikal bebas dalam suatu bahan atau tanaman yaitu kandungan senyawa yang terdapat pada bahan tersebut, seperti flavonoid dan fenol (Andriani et al., 2019). Selain itu perbedaan metode ekstraksi dan perbedaaan tempat pengambilan bahan atau tanaman juga berpengaruh terhadap kandungan senyawa dalam bahan tersebut.

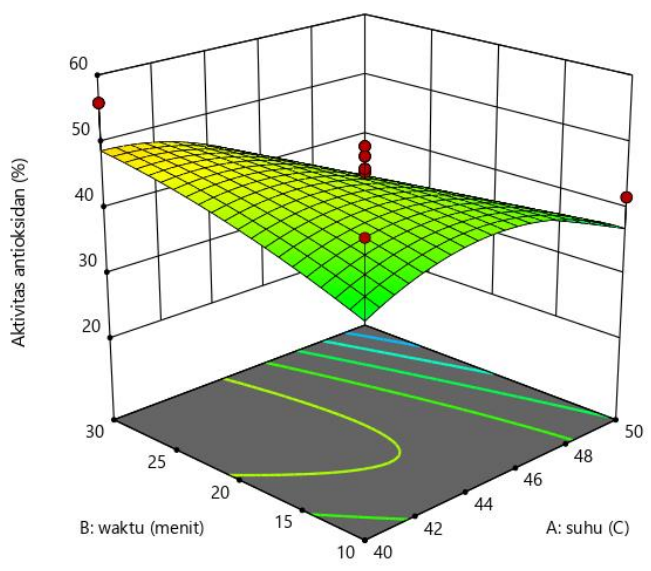

(b)

(a)

Gambar 2. Contour Plot 2D terhadap aktivitas antioksidan (a)

Surface plot 3D terhadap aktivitas antioksidan (b)

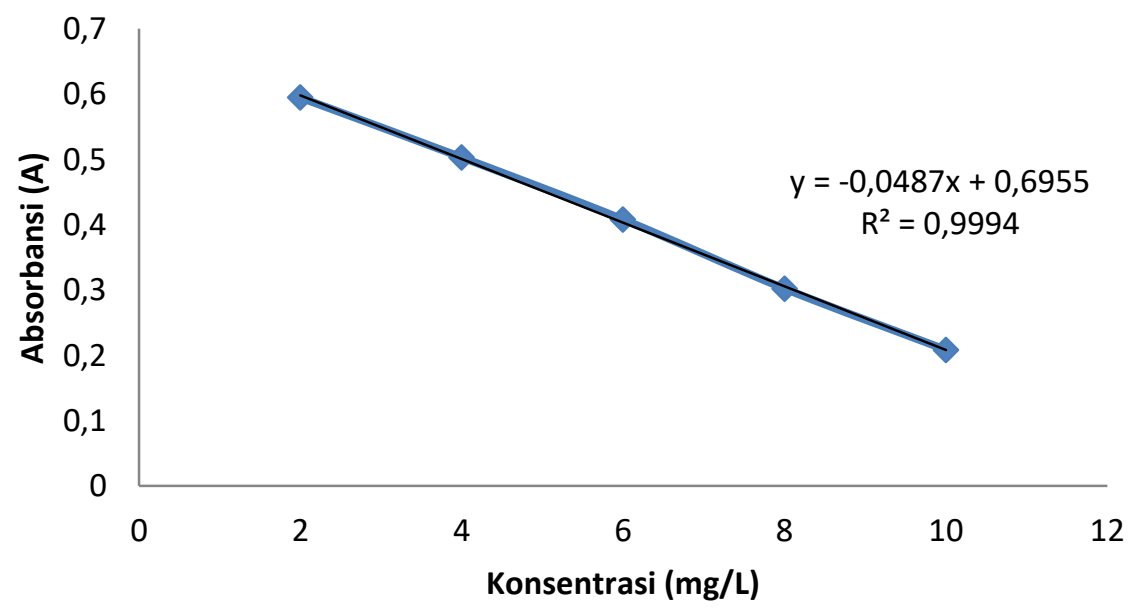

Gambar 3. Grafik kontrol vitamin C 
Berdasrkan Gambar 2 hasil optimum aktivitas penangkal radikal bebas daun binahong tertinggi ditandai dengan warna kuning sedangkan hasil terendah pada daerah berwarna biru. Pada gambar tersebut dapat dilihat bahwa Surface plot 3D tidak membentuk parabola dikarenakan faktor-faktor atau variabel tidak berkaitan atau berhubungan dengan aktivitas penangkal radikal bebas, sehingga model yang digunakan tidak tepat. Karena aktivitas penangkal radikal bebas suatu bahan atau sampel dipengaruhi oleh kandungan senyawa pada bahan atau sampel.

Pembanding yang digunakan pada pengujian aktivitas penangkal radikal bebas yaitu vitamin $\mathrm{C}$. Dalam pengujian vitamin $\mathrm{C}$ dibuat terlebih dahulu larutan induk $100 \mathrm{mg} / \mathrm{L}$ yang diambil dari larutan $1000 \mathrm{mg} / \mathrm{L}$, kemudian dibuat 5 deret yaitu 2, 4, 6, 8 , dan $10 \mathrm{mg} / \mathrm{L}$. Tujuan pembuatan konsentrasi yaitu untuk membandingkan aktivitas penangkal radikal bebas daun binahong dengan vitamin $\mathrm{C}$. Vitamin $\mathrm{C}$ merupakan penangkal radikal bebas alami yang sangat kuat sehingga digunakan sebagai pembanding.

Dari Gambar 3 diperoleh bahwa nilai $\mathrm{R}^{2}$ 0,9994 mendekati nilai 1. Pada hasil optimasi penangkal radikal bebas ekstrak daun binahong pada suhu 40 waktu 30 menit diperoleh nilai persentase inhibisi $55,92 \%$ setara dengan persentase inhibisi vitamin $\mathrm{C}$ diantara konsentrasi $6 \mathrm{mg} / \mathrm{L}$ dan $8 \mathrm{mg} / \mathrm{L}$. Kemampuan aktivitas penangkal radikal bebas daun binahong berkaitan dengan senyawa flavonoid yang terkandung pada daun binahong. Senyawa flavonoid dan fenol sangat berkaitan dengan aktivitas antioksidan, sehingga semakin tinggi kandungan flavonoid dan fenol pada bahan maka semakin tinggi pula aktivitas antioksidannya (Zuraida et al., 2017). Selain flavonoid dan fenol, metabolit sekunder lainnya seperti terpenoid dan alkaloid juga dapat sebagai antioksidan (Antony et al., 2011). Menurut (Al-jaber et al., 2011) bahwa alkaloid, flavonoid, polifenol, terpenoid dan tanin dapat berperan sebagai antioksidan.

Perbandingan nilai prediksi dengan nilai aktual hasil optimasi yang diperoleh dari RSM yaitu 48,85 \% sedangkan nilai aktual yang diperoleh dari hasil penelitian yaitu 55,92 \% dengan nilai residual standar error 7,08\%. Dari nilai residual standar error melebihi 5\% yang artinya berbeda dengan prediksi atau data yang diperoleh tidak menyebar dengan normal, yang berarti nilai aktual tidak mendekati nilai prediksi. Nilai residual standar error yaitu selisih antara nilai respon dengan nilai respon aktual yang diprediksikan.

Hasil uji Analysis of Variance (ANOVA) terhadap aktivitas penangkal radikal bebas atau persentase inhibisi yaitu didapatkan nilai $\mathrm{P} 0,2511$ $(>5 \%)$ atau tidak signifikan dimana variabel tidak berpengaruh nyata terhadap respon aktivitas penangkal radikal bebas. Nilai lack of fit yang diperoleh yaitu P-value 0,1267 $(>0,05)$ atau tidak signifikan terhadap ketidaktepatan artinya model yang digunakan sudah sesuai. Nilai $R^{2}$ yaitu 0,5493 atau $54,93 \%$ dan nilai Adjusted $\mathrm{R}^{2}$ yaitu 0,2273 atau $22,73 \%(<70 \%)$ sehingga model yang digunakan tidak sesuai dan tidak dapat digunakan untuk memprediksi respon aktivitas penangkal radikal bebas dengan menggunakan variabel suhu dan waktu ekstraksi. Nilai adjusted $\mathrm{R}^{2}$ akan terjadi penurunan apabila variabel yang digunakan tidak memberikan pengaruh.

Diperoleh persamaan kanonikal yang diperoleh dari analisis model dan ragam :

$\mathrm{Y}=44,57-6,16 \mathrm{~A}-0,2843 \mathrm{~B}-5,77 \mathrm{~A} * \mathrm{~B}-5,97$ $\mathrm{A}^{2}-1,41 \mathrm{~B}^{2}$

Keterangan :

$\mathrm{Y}=$ Aktivias Penangkal radikal bebas (\%)

$\mathrm{A}=\operatorname{Suhu}\left({ }^{\circ} \mathrm{C}\right)$

$\mathrm{B}=$ Waktu (Menit)

$\mathrm{A} * \mathrm{~B}=$ Interaksi suhu dan waktu

$\mathrm{A}^{2} \quad=$ Waktu ditingkatkan dua kali

$\mathrm{B}^{2} \quad=$ Waktu ditingkatkan dua kali

Pada persamaan diatas menunjukkan bahwa aktivitas penangkal radikal bebas tidak dipengaruhi oleh faktor suhu dan waktu sehingga pada hasil persamaan bernilai negatif.

\section{KESIMPULAN}

Pada suhu $45^{\circ} \mathrm{C}$ dan waktu 20 menit diperoleh kondisi optimum ekstraksi berbantu gelombang ultrasonik terhadap persentase rendemen dengan nilai rendemen 10,44\% dengan analisis RSM dan ekstrak daun binahong memiliki aktivitas penangkal radikal bebas paling optimum pada suhu $40^{\circ} \mathrm{C}$ dengan waktu ekstraksi 30 menit diperoleh nilai persentase inhibisi yaitu 55,92\%.

\section{DAFTAR PUSTAKA}

Al-jaber, N. A., Awaad, A. S., \& Moses, J. E. (2011). Review on some antioxidant plants growing in Arab world. Journal of Saudi Chemical Society, 15(4), 293-307. https://doi.org/10.1016/j.jscs.2011.07.004 
Andriani, M., Permana, I.D.G.M., Widarta, I.W.R. (2019). Pengaruh Suhu Dan Waktu Ekstraksi Daun Belimbing Wuluh (Averrhoa bilimbi L .) Terhadap Aktivitas Antioksidan Dengan Metode Ultrasonic Assisted Extraction (UAE). Jurnal Ilmiah Fitofarmaka. 8(3), 330-340.

Antony, M., Menon, D. B., James, J., S, L. D. M., Arun, K., \& Thankamani, V. (2011). Phytochemical analysis and antioxidant activity of Alstonia scholaris. 3(26), 13-18. https://doi.org/10.5530/pj.2011.26.3

Arif, R., Wardatun, S., \& Weandarlina, I. Y. (2008). Isolasi dan identifikasi senyawa saponin ekstrak metanol daun. Jurnal Farmasi, 3-8.

Ayu, P., Surbakti, A., Queljoe, E. De, \& Boddhi, W. (2018). Skrining Fitokimia Dan Uji Toksisitas Ekstrak Etanol Daun Binahong (Andredera cordifolia (Ten.) Steenis) Dengan Metode Brine Shrimp Lethality Test (BSLT). Pharmacon, 7(3), 22-31. https://doi.org/10.35799/pha.7.2018.20112

Cahayanti, I.A.P.A., Wartini, N.M., Wrasiati., L.P. 2016. Pengaruh Suhu dan Waktu Ekstraksi Terhadap Karakteristik Pewarna Alami Buah Pandan. Jurnal Rekayasa dan Manajemen Agroindustri. 4(2), 32-41.

Badan, K., Obat, P., \& Makanan, D. A. N. (2019). Peraturan Badan Pengawas Obat dan Makanan Republik Indonesia Nomor 32 Tahun 2019 tentang Persyaratan Keamanan dan Mutu Obat Tradisional, Berita Negara Republik Indonesia Tahun 2019 Nomor 1294. 1294.

Ibrahim, A. martua, Yunianta, \& Sriherfyna, F. H. (2015). Effect of Temperature and Extraction Time on Physicochemical Properties of Red Ginger ( Zingiber officinale var. Rubrum ) Extract with The Additional of Honey Combination as Sweetener for Functi. Jurnal Pangan Dan Agroindustri, 3(2), 530-541.

Jami'ah, S. R., Ifaya, M., Pusmarani, J., \& Nurhikma, E. (2018). Uji Aktivitas Antioksidan Ekstrak Metanol Kulit Pisang Raja (Musa Paradisiaca sapientum) Dengan Metode DPPH (2,2-Difenil-1Pikrilhidrazil). Jurnal Mandala Pharmacon Indonesia, 4(1), 33-38. https://doi.org/10.35311/jmpi.v4i1.22

Kurniawan, B., \& Aryana, W. F. (2015).
Binahong (Cassia Alata L) As Inhibitor Of Escherichia Coli Growth. Faculty of Medicine Lampung University, 4(4), 100104.

Kunarto, B., Sutardi., Supriyanto., Anwar, C. (2019). Optimasi Ekstraksi Berbantu Gelombang Ultrasonik pada Biji Melinjo Kerikil ( Gnetum gnemon L ., ' Kerikil ') Menggunakan Response Surface Methodology. 8(3), 1-8.

Moniharapon, P. J., Queljoe, E. De, \& Simbala, H. (2016). Identifikasi Fitokimia Dan Uji Aktivitas Antioksidan Ekstrak Etanol Tauge (Phaseolus Radiatus L.). Pharmacon, 5(4), 130-136. https://doi.org/10.35799/pha.5.2016.13983

Parwati, N., Napitupulu, M., \& Diah, A. (2014). Uji Aktivitas Antioksidan Ekstrak Daun Binahong (Anredera Cordifolia (Tenore) Steenis) dengan 1,1-Difenil-2-Pikrilhidrazil (DPPH) Menggunakan Spektrofotometer UV-Vis. Jurnal Akademika Kimia, 3(4), 206-213.

Sari, B. L., Susanti, N., \& Sutanto, S. (2015). Skrining Fitokimia dan Aktivitas Antioksidan Fraksi Etanol Alga Merah Eucheuma spinosum. Pharmaceutical Sciences and Research, 2(2), 59-68. https://doi.org/10.7454/psr.v2i1.3331

Sekarsari, S., Widarta, I. W. R., \& Jambe, A. A. G. N. A. (2019). Pengaruh Suhu Dan Waktu Ekstraksi Dengan Gelombang Ultrasonik Terhadap Aktivitas Antioksidan Ekstrak Daun Jambu Biji (Psidium guajava L.). Jurnal Ilmu Dan Teknologi Pangan (ITEPA), $\quad 8(3), \quad 267$. https://doi.org/10.24843/itepa.2019.v08.i03. p05

Utami, N.F., Nhestricia, N., Maryanti, S., Tisya, T., Maysaroh, S. 2018. Uji Aktivitas Antioksidan Dari Biji Kopi Robusta (Coffea canephora P.) Berdasarkan Perbedaan Ekologi Dataran Tinggi di Pulau Jawa. Fitofarmaka Jurnal Ilmu Farmasi8(1), 6772.

Zuraida., Sulistiyani., Sajuthi, D., Suparto, I.H. 2017. Fenol, Flavonoid, Dan Aktivitas Antioksidan Pada Alstonia scholaris $R$. Br Stem Bark Extract ). 35(3), 211-219. https://doi.org/10.20886/jphh.2017.35.3.21 $1-219$ 